Vol. 2, No. 1, Januari 2018, 92-102

Available Online at https://ejournal.warmadewa.ac.id/index.php/kulturistik

DOI: dx.doi.org/10.22225/kulturistik.2.1.679

\title{
LINGUISTIC ERRORS OF USING INDONESIAN IN FOREIGN LEARNERS' WRITINGS
}

\author{
Ni Wayan Sri Darmayani \\ Universitas Udayana \\ iluhanik@rocketmail.com \\ Ketut Artawa \\ Universitas Udayana \\ tutartawa@gmail.com \\ Made Sri Satyawati \\ Universitas Udayana \\ srisatyawati@gmail.com
}

\begin{abstract}
This research was aimed at describing errors of using Indonesian in foreign learners' writings and understanding causing factors of those errors. This research applied qualitativedescriptive approach method. The data were sixteen Indonesian writings written by foreign learners. The findings of this study reveal that there are such linguistic errors related to spelling, such as: errors in capitalization, error in writing affixed and root words, error in writing numbers, error in using punctuations, and error in writing borrowed word; related to morphology, such as: error in using the root, error in morphophonemic process, and error in using affixes; related to syntax, such as: errors in phrase structure and errors in sentence structure; and related to lexicon, such as: the use of pleonastic words, errors in word choice, and the use of unnecessary interrogative words. Moreover, the causing factors of those errors are linguistic and non-linguistic factors. Linguistic factors can be classified into three factors, they are interlingual factor, intralingual factor, and the daily use of Indonesian. Meanwhile, non-linguistic factors can be classified into two factors, they are imperfect language learning and learner's community environment.
\end{abstract}

Keywords: Indonesian writing, foreign learner, linguistic errors, the causing factors of errors

\section{INTRODUCTION}

Indonesian has been attracting attention of the world. Since Asian Economy Community (AEC) in 2015, many foreigners from various countries come to Indonesia to learn Indonesian. Because of this condition, there are many Indonesian courses for foreigners, approximately 45 educational institutions in Indonesia (Balai Pengembangan dan Pembinaan Pustaka, 2016).

The purposes of learning Indonesian are various and related to their needs. The purposes into two major purposes, they are general purpose and particular purpose. In general, foreigners learn Indonesian to commiunicate with Indonesian native speakers in daily interaction. Meanwhile, in particular, foreigners learn Indonesian to understand Indonesian culture (Suyitno, 2007: 63).

To accomplish their purposes, foreigners are supposed to master Indonesian 
in spoken and written language. However, they generally only understand spoken language and often make errors when they use Indonesian in writing. Meanwhile, good written language is required to express idea, feeling, and experiences clearly, coherently, and logically to others in writing.

Several studies analyzed errors of using Indonesian in foreign learners' writings. Affixation errors which were found in foreign learners' writings at class IX junior high school of Bandung International School. There are three types of affixation errors, they are error in using the root, error in morphophonemic process, and error in using affixes. She also explained the causing factors of those errors, they are interlingual interference, intralingual transfer, community environment, and strategy of communication (Widawati, 2007).

In her research, Nugraha investigated errors in using Indonesian which were made by foreign learners at Indonesian Language and Culture Intensive Course (ILCIC) in their writings. Those errors consist of uneffective sentence, error in diction; errors in using affixes, conjunction, preposition, 'yang'; error in using plural, error in passive voice, and incomplete sentence function. To reduce those errors, he suggested remedial teaching strategy. The strategy consists of five steps, they are: giving explanation about the errors that are made by foreign learners, giving correction either in a pair or individual, giving the right example, giving morphological rules and synonym in specific context, and discussing the causing factors of those errors with foreign learners (Nugraha, 2008).

Pratiwi divided errors which were found in foreign learners' writings from Thailand into four major types. Those four major types of errors are spelling errors, errors in word choice, incomplete sentence functions, and interferences. Spelling errors are classified into errors in using capital letters, writing sentence without full stop, using preposition and conjunction, writing morpheme, and using phoneme. Errors in word choice are classified into error in choicing adjective, omission of affixes, error in using words as complement and predicate, and error in deciding subject. Incomplete sentence functions are classified into omission of adverb and error in organizing adverb. Interferences are classified into interference of Malay and English. Those errors are caused by learners' limited competence of using Indonesian (Pratiwi, Rahmawati., \& Huda, 2016).

Siagian discussed errors in using Indonesian as a foreign language which were made by advanced learners at Universitas Yale, USA in their writings. Those errors consist of errors in word choice, errors in sentence structure, the use of ineffective sentences, and the use of informal language. He also explained the causing factors of those errors, they are interlingual interference and learners' limited competence of mastering Indonesian rules and vocabularies (Siagian, 2017).

Error is a part of conservation that deviates from some selected norms of nature language performance (Dulay, Marina Burt, \& Krashen, 1982: 138). Making errors is a natural process of learning and must be considered as a part of cognition (Brown, 2007). Errors describe learners' competence of target language rules (Tarigan \& Djago Tarigan, 2011: 68). Learners make a lot of errors when they do not master target language rules. On the other hand, errors decrease when learners' competence of target language rules improves.

A technique for identifying, classifying, and systematically interpreting the unacceptable forms of a language in the production data of someone learning either a second or foreign language is named Error Analysis (EA) (Richards \& 
Schmidt, 2002: 73). Corder pointed out positive values of identifying learners' errors. Error gives indication to the teacher about learners' learning progress and their difficulties in learning the target language. Then, the teaching strategies are able to be organized based on it. Besides, error is considered as a device for learners to test out their competence of target language rules and then find appropriate approach to improve their language competence (Corder, 1973).

Foreign learners also make linguistic errors in their Indonesian writings. It can be seen in the sentence Saya ikut bahasa Indonesia kelas karna saya malas belajar sendiri. In noun phrase bahasa Indonesia kelas, the learner missordered the head and the modifier. Kelas is the head and bahasa Indonesia is the modifier. The learner applied English rule in ordering them, it is Modifier-Head. Meanwhile, the standard structure of noun phrase in Indonesian is Head-Modifier. Therefore, the correct noun phrase is kelas bahasa Indonesia.

Verb in that sentence above must be a transitive verb because it is followed by an object. In this case, affixes meng-/ $-i$ must be affixed step by step. First, suffix $-i$ is affixed in the root $i k u t$ to form the complex base $i k u t i$. Then, to form a transitive verb mengikuti, prefix meng-is affixed in the complex base ikuti.

Besides, the learner made spelling error in writing noun conjunction karna. The learner is not familiar with the standard words and applied unstandard spoken language which is used by several speaker. In Indonesian dictionary, the standard writing of this conjunction is karena.

The learner also made error in word choice. It can be seen in the sentence Kita tinggal selama lima bulan di Indonesia tahun ini. In English pronoun that refers to first plural person is only we. Meanwhile, in Indonesian there are two pronouns that refer to first plural person, they are kami and kita. Pronoun kami is used when the person spoken to is excluded, while pronoun kita is used when the person spoken to is included. Therefore, the correct pronoun is kami.

Those errors complicate readers to understand the idea that want to be delivered by the writer. Therefore, an investigation of learners' errors, particularly foreign learners' errors of using Indonesian in writing, is important. Although this is a preliminary research and very simple, at least foreign learners' difficulties in learning Indonesian are able to be identified. Besides, the weaknesses of teaching Indonesian, particularly in vocational class, and other causing factors are able to be known. questions.

Based on the background, this study attempted to answer the following

1) What linguistics errors are made by foreign learners in Indonesian writing?

2) What are the causing factors of those errors?

This study is aimed at identifying foreign learners' errors of using Indonesian in writing and investigating the causing factors of those errors.

\section{METHOD}

This study is a qualitative descriptive research which place emphasis on the categories of linguistic errors made by foreign learners in their Indonesian writings and the causing factors of those errors.

Data were taken from foreigners who learn Indonesian in Cinta Bahasa. Its head course is in Ubud, Bali and branch courses are in Sanur, Canggu, and Kuta. Cinta Bahasa cooperates with Balai Bahasa of Bali Province in language train- 
Vol. 2, No. 1, Januari 2018, 95

Available Online at https://ejournal.warmadewa.ac.id/index.php/kulturistik DOI: dx.doi.org/10.22225/kulturistik.2.1.679

ing. It has Indonesian private and group classes for beginner, intermediate, and advanced. The teachers are Indonesian native speakers and they use Indonesian during teaching.

Participants of this research are intermediate learners who speak English as mother tongue. Learners were instructed to write two Indonesian writings individually by choosing some topics in the syllabus and did not look up dictionaries, online resources, etc. In the other words, they write it based on their own competence. By using a purposive sampling technique, sixteen writings were collected from fourteen learners as data in this research. Those writings show different categories of errors.

The writings were investigated to identify any ill-formed sentences. However, only seventy five ill-formed sentences are chosen as data. Each sentence contains a number of errors. Meanwhile, other ill-formed sentences which have same categories of errors are eliminated. Then, an analysis was done by classifiying the errors, describing them, and giving the well-formed sentences. Next, for finding out the causing factors of those errors, learners were interviewed and the questionnaires were answered by the teachers.

\section{DISCUSSION}

Having analyzed the whole data, the result indicates that foreign learners made linguistic errors in their Indonesian writings related to spelling, morphology, syntax, and lexicon. The classification of those errors is shown in the table.

Tabel 1 The classification of Linguistic Errors

\begin{tabular}{ll}
\hline & \multicolumn{1}{c}{ Linguistic Errors } \\
\hline Categories & Sub Categories \\
\hline Spelling Errors & Errors in capitalization \\
\cline { 2 - 2 } & Error in writing affixed and root words \\
\cline { 2 - 2 } & Error in writing numbers \\
\cline { 2 - 2 } Errors & $\begin{array}{l}\text { Error in using punctuations, such as omission of full stop, comma, } \\
\text { and hyphen, and addition of comma }\end{array}$ \\
\cline { 2 - 2 } & Error in writing borrowed word \\
\hline Syntactic Errors & Error in using the root \\
\cline { 2 - 2 } & Error in morphophonemic process \\
\cline { 2 - 2 } & $\begin{array}{l}\text { Error in using affixes, such as the use of incorrect affix and omis- } \\
\text { sion of affixes (omission of prefix ber-, meng-, and se-, and affixes } \\
\text { meng-/-kan, meng-/-i, di-/-kan, ter-/-kan, pe-/-an, and per-/-an) }\end{array}$ \\
\hline $\begin{array}{l}\text { Errors in phrase structure, such as omission of preposition, error in } \\
\text { pord order, double marking of pluralization, errors in phrase ex- } \\
\text { omission of conjunction yang), omission of possessive pronoun, } \\
\text { and the use of pattern Dimiliki + dari + Pemilik }\end{array}$ \\
\cline { 2 - 2 } & $\begin{array}{l}\text { Errors in sentence structure, such as incompleteness grammatical } \\
\text { functions (omission of subject, omission of predicate, and omission } \\
\text { of object in transitive verb), double subject, error in passive voice, } \\
\text { omission of conjunction }\end{array}$ \\
\hline The use of pleonastic words \\
\cline { 2 - 2 } & Errors in word choice \\
\cline { 2 - 2 } The use of unnecessary interrogative words \\
\hline Lexical Errors
\end{tabular}


Vol. 2, No. 1, Januari 2018, 96

Available Online at https://ejournal.warmadewa.ac.id/index.php/kulturistik

DOI: dx.doi.org/10.22225/kulturistik.2.1.679

\section{Linguistics Errors}

1. Spelling Errors

Spelling is the writing of a word with the necessary letters and diacritics present in an accepted standard order and an arrangement of letters that form a word or part of a word. Spelling difficulties can lead to substantial problems in the literacy acquisition.

Error identification : Sebelum Saya pindah ke sini, Saya berajar bahasa Indonesia 3 minggu di Wisma Bahasa, Jogjakarta.

In the sentence above there are such spelling errors. First, the writing of personal pronoun saya must be written in lowercase letter, not in capital/uppercase letter, except if it is in the beginning of sentence. Next, the writing of number is incorrect because the number consists of one word and it is not used in sequence. Therefore, the number must be spelled out in words rather than numerical.

Besides, the learner made a morphological error by using affixed verb berajar. Based on morphophonemic rules, prefix ber-becomes bel- when it is affixed in the root ajar. Therefore, the correct affixed verb is belajar.

Correction : Sebelum saya pindah ke sini, saya belajar bahasa Indonesia tiga minggu di Wisma Bahasa, Jogjakarta.

Another example of spelling errors can be seen in the sentence below. The learner made errors in using punctuation, particularly comma.

Error identification : Pada akhir minggu, kami makan telur, babi dan tomat bakar untuk makan pagi.

Adverb describes or gives more information about a verb, adjective, adverb, or phrase. It has various types which expresses some relations of manner or quality, place, time, degree, number, etc. In the sentence above pada akhir minggu is adverb of time. The attendance of adverb in the sentence is optional. Moreover, adverb is easily to be moved. It is able to be replaced in the beginning, in the middle, or in the end of the sentence. When adverb is in the beginning of the sentence, it is written without comma.

On the other hand, telur, babi, dan tomat bakar is details of the object in the sentence above. Therefore, comma must be used in between the details.

Correction : Pada akhir minggu kami makan telur, babi, dan tomat bakar untuk makan pagi.

\section{Morphological Errors}

Morphology is related to the construction of words and parts of words. When the word is not modified based on the rules, it has an impact on the affixed word as the result of affixation related to its meaning, class, or grammatical function (Bloomfield, 1995:200).

Error identification : Kalau ada anak lain, dia harus diberikan uang sebagai kompensasi juga, supaya tidak ada tengkar.

Tengkar is dependent root. Dependent root is able to be used in the utterance after it is previously affixed, repeated, or combined with other words. Therefore, affixs per-/-an must be affixed all at once in the root tengkar. The affixation will form the affixed noun pertengkaran.

Correction : Kalau ada anak lain, dia harus diberikan uang sebagai kompensasi juga, supaya tidak ada pertengkaran.

The learner also made morphological errors by using incorrect affix as shown in the data below. The use of incorrect affix has an impact on the word class and grammatical function of the affixed word.

Error identification : Saya harus latihan dan belajar dengan guru karena saya ingin memperbaiki bahasa Indonesia saya.

The use of suffix -an in the root latih is incorrect because the function of suffix $a n$ is to form a noun. On the other hand, the sentence above requires an affixed verb which will function as predicate. The correct affix that must be affixed in the root latih is prefix ber-because the function of prefix ber-is to form an intransitive verb. 
Vol. 2, No. 1, Januari 2018, 97

Available Online at https://ejournal.warmadewa.ac.id/index.php/kulturistik

DOI: dx.doi.org/10.22225/kulturistik.2.1.679

Correction

: Saya harus berlatih dan belajar dengan guru karena saya ingin memperbaiki bahasa Indonesia saya.

\section{Syntactic Errors}

Syntax is the study of the principles and process by which sentences are constructed in particular language. When the aspects of sentence are not constructed properly, the idea is not able to be conveyed completely or even it is not able to be understood (Chomsky, 1971:110).

Error identification : Owen tidur sekitar jam delapan, kemudian, kami tonton televisi atau baca banyak buku-buku sampai kami capek.

Noun phrase banyak buku-buku has double marking of pluralization. Meanwhile, based on Indonesian rules, it must has one marking of pluralization. There are two steps to form the standard noun phrase. First, pluralization is marked by repeating the noun and the determiner which marks pluralization is eliminated as shown in the correction (1). Second, if the determiner which marks pluralization is used, the noun is not repeated as shown in the correction (2).

Besides, the learner also made morphological errors. Prefix meng- must be affixed in the root tonton and baca. Prefix meng- turns into men- when it is affixed in the root which is started by consonant $/ \mathrm{t} /$, such as tonton. In addition, consonant $/ \mathrm{t} / \mathrm{is}$ assimilated by nasal of the prefix. Therefore, the affixation forms verb menonton. Meanwhile, when prefix meng- is affixed in the root which is started by consonant $/ \mathrm{b} /$, such as baca, it turns into $m e m$-. Therefore, the affixation forms the affixed verb membaca.

The learner made errors in word choice by using jam instead of pukul. The use of jam in the adverb of time jam delapan is incorrect because jam is used to indicate period of the time in hours. Meanwhile, pukul is used to point out the time in that moment. Therefore, pukul is the appropriate word for that adverb of time. The same error was also made by the learner by using capek instead of capai. The use of adjective capek is incorrect because capek is informal word used in daily conversation. It is not appropriate to be used in written language. The correct adjective is capai based on the standard Indonesian dictionary.

Correction (1) : Owen tidur sekitar pukul delapan, kemudian, kami menonton televisi atau membaca buku-buku sampai kami capai.

Correction (2) : Owen tidur sekitar pukul delapan, kemudian, kami menonton televisi atau membaca banyak buku sampai kami capai.

Another example of error in phrase structure is shown in the sentence below.

Error identification : Aktivitas yang saya tidak suka adalah rapat.

The subject in that sentence, aktivitas, is expanded by personal pronoun passive clause. In that passive clause, yang is conjunction, saya is the author of an action (pelaku), tidak is auxiliary (aspek), and suka is verb (kata kerja). However, the pattern is incorrect. Based on Indonesian rules, the standard pattern of passive clause is (aspek) + pelaku + kata kerja as shown in the correction.

Besides, suffix $-i$ must be affixed in the root suka. The function of suffix $-i$ is to form a transitive verb which is able to be used to define the subject in the relative clause with pattern yang + aspek + pelaku + kata kerja. The affixation will form the affixed verb sukai.

Correction : : Aktivitas yang tidak saya sukai adalah rapat.

The learner also made a syntactic error in the sentence below.

Error identification : Satu tahun yang lalu kembali ke Australia.

Based on Indonesian rules, a sentence consists of at least two grammatical functions, they are subject and predicate. However, the sentence above does not have a subject, it has only a predicate. Subject indicates what it is about or who/what performs the action. Subject in the sentence above can be fulfilled by pronoun kami. Pronoun kami is pronoun that refers to first plural person used when the person spoken to is excluded. Correction : Satu tahun yang lalu kami kembali ke Australia. 
Vol. 2, No. 1, Januari 2018, 98

Available Online at https://ejournal.warmadewa.ac.id/index.php/kulturistik

DOI: dx.doi.org/10.22225/kulturistik.2.1.679

\section{Lexical Errors}

When words are chosen appropriately, the language structure will be held together. Moreover, the intended meaning is able to be conveyed clearly. On the other hand, when words are selected improperly and inaccurately, it will lead to the confusion and segmentation of meaning.

Error identification : Waktu itu, Saya hanya berajar kata kata mudah saja, Saya belum bisa bicara.

The use of two words or more which have same meaning or function is called pleonasm. It is shown in the use of words hanya and saja. Hanya and saja have same function, it is to place a limit on anything. Therefore, it is not correct to use all at once.

Besides, the use of waktu itu is incorrect because it is not adverb of time. The appropriate adverb of time is pada saat itu.

The learner also made morphological errors. First, the learner used incorrect affixed verb berajar. Based on morphophonemic rules, prefix ber-becomes bel- when it is affixed in the root ajar. Therefore, the correct affixed verb is belajar. Next, prefix bermust be affixed in the root bicara to form an intransitive verb. The affixation will form intransitive verb berbicara.

In the sentence above there are such spelling errors. First, the writing of personal pronoun saya should be not written in capital/uppercase letter, except if it is in the beginning of sentence. It must be written in lowercase letter. Next, reduplicated word kata-kata is written without hypen. Hyphen is used to link reduplicated word.

The sentence above is a complex sentence which consists of two clauses, they are main clause and subordinate clause. However, there is no conjunction for combining those clauses. Therefore, conjunction sehingga must be added. The function of conjunction sehingga is to combine-describe the consequence of what has mentioned in the main clause.

Correction (1)

: Pada saat itu saya hanya belajar kata-kata mudah sehingga saya belum bisa berbicara.

Correction (2) : : Pada saat itu saya belajar kata-kata mudah saja sehingga saya belum bisa berbicara.

In the sentence below the learner made lexical error by using unnecessary interrogative word.

Error identification $\quad$ : Masakan Indonesia pakai banyak bumbu dan susah untuk tahu bumbu yang mana harus di pakai.

Interrogative word is typically associated with a discourse function of questions that are used to seek information. However, the sentence above is not interrogative sentence. Therefore, the use of interrogative word yang mana is not appropriate and must be replaced by conjunction yang. Conjunction yang is used to give definition of the noun.

The learner also made an error in writing affixed word because the learner was not able to differentiate between prefix $d i$ - and preposition $d i$. Prefix $d i$ - is affixed in the root which is a verb and written as a single word. Meanwhile, preposition $d i$ is used at the beginning of noun and written with a space in between. Because the root pakai is a verb, diis a prefix and it must be written as a single word with the root.

Besides, there are such morphological errors in the sentence above. Prefix mengmust be affixed in the root pakai. However, prefix meng- turns into mem- when it is affixed in the root which is started by consonant /p/, such as pakai. Moreover, consonant /p/ is assimilated by nasal of the prefix. Therefore, the affixation forms verb memakai. Meanwhile, the root tahu is affixed step by step. First, suffix $-i$ is affixed in the root tahu to form the complex base tahui. Then, prefix ke- is affixed in the complex base tahui to form the complex base ketahui. Next, prefix meng- is affixed in the complex base ketahui. In this case, consonant $/ \mathrm{k} /$ is assimilated by nasal of the prefix. Therefore, the affixation will form verb mengetahui.

Correction

: Masakan Indonesia memakai banyak bumbu dan susah untuk mengetahui bumbu yang harus dipakai. 
Vol. 2, No. 1, Januari 2018, 99

Available Online at https://ejournal.warmadewa.ac.id/index.php/kulturistik

DOI: dx.doi.org/10.22225/kulturistik.2.1.679

\section{The Causing Factors of the Errors}

1. Linguistic factors

Linguistic factors consist of interlingual factor, intralingual factor, and the daily use of Indonesian. Those factors are further explained by giving examples.

1) Interlingual factor

Mother tongue affects the learning process of target language, and even more it has implication in the errors of using target language. The learner carries over the existing knowledge of his/her mother tongue to the performance of target language (Ellis, 1986:28). If the rules of his/her mother tongue and the target language have similarities, the learner is able to master the target language easily. On the other hand, if the rules of his/her mother tongue and the target language have many differences, the learner will be hard to master the rules of target language, and even more he/she will makes interlingual errors as shown below.

Error identification : Saya mau ikut bahasa Indonesia kelas....

In noun phrase above the head is kelas, while the modifier is bahasa Indonesia. However, the learner applied the ordering rule of noun phrase in English, it is ModifierHead. That structure is not acceptable in Indonesian because the standard structure is Head-Modifier. Therefore, the correct noun phrase is kelas bahasa Indonesia.

Error identification : saya telah mendapat kesempatan untuk berbicara di depan 170 mahasiswa dari Fakultas Ekonomi dan Bisnis (FEB), Universitas Brawijaya di kota Malang....

The possesive structure of phrase above is dimiliki + dari + pemilik. It is the possesive structure in English. The learner imitated that possesive structure in composing phrase in Indonesian. However, the standard possesive structure in Indonesian is dimiliki + pemilik. Therefore, preposition dari is not necessary.

2) Intralingual factor

Learners make intralingual errors because of ineffective traits of target language learning, such as over-generalization, ignorance of rule restrictions, and incomplete application of rules. The examples of intralingual error are explained below.

Error identification : Masakan Indonesia pakai banyak bumbu dan susah untuk tahu bumbu yang mana harus di pakai.

An error in data above was made by the learner because the learner over generalized $d i$ - as prefix and $d i$ as preposition. Over-generalization is the consequence of learner's effort in reducing learning assessment of target language rules. Based on standard Indonesian rules, $d i$ - as prefix is a match for verb and written as a single word with the root, while $d i$ as preposition is a match for noun and written apart from the noun. Because the root pakai is a verb, di- is affixed as prefix and written as a single word with the root.

Error identification : Saya juga belajar pada tahun 1995 sebagai mahasiswi pertukaran selama 3 bulan di Universitas Pattimura, Ambon dari Charles Darwin University, Darwin.

Based on Indonesian spelling rules, numbers which consist of one or two words are spelled out in words, except if the numbers are used in sequence. However, the learner was not aware of the rule restriction and it caused the error in writing number as seen in data. Number in data above must be spelled out in words rather than numerical.

Error identification : Dia hadiahkan ke saya.

The affixed verb that should function as predicate in the sentence above is menghadiahkan. To form transitive verb menghadiahkan, meng-/-kan must be affixed step by step. First, suffix -kan is affixed in the root hadiah to form the complex base hadiahkan. Then, prefix meng- is affixed in the complex base hadiahkan. However, in data above the learner did not apply the complete rules of affixation. The learner was only interested in communication and was not aware of the complete application of affixation rules. Meanwhile, by applying the complete rules, the idea is able to be understood clearly. 
Vol. 2, No. 1, Januari 2018, 100

Available Online at https://ejournal.warmadewa.ac.id/index.php/kulturistik

DOI: dx.doi.org/10.22225/kulturistik.2.1.679

3) The daily use of Indonesian

Learners' language competence is affected by the daily use of target language in their community environment. If learners interact with native speakers of the target language who use unstandard language, learners gradually avoid the standard language and replace it with the unstandard language as shown below.

Error identification : Di sini yang paling mudah untuk praktek bicara bahasa indonesia adalah dengan remaja yang belajar bahasa inggris.

In data above the learner made an error in writing borrowed word because of the confusion of standard writing of borrowed word which is found by the learner in various writings, such as newspaper and billboard and heard from his/her community environment. The confusion has an impact on the use of Indonesian in writing. The learner avoided to use praktik which is the standard borrowed word from Dutch and prefered to use incorrect borrowed word praktek.

Error identification : Untuk selesaikan perjalanan, kamu perlu waktu tujuh sampai delapan jam, tetapi orang lain membilang sebelas jam.

In data above the learner used unstandard root because the language that he/she uses in daily interaction with Indonesian native speakers is unstandard. Therefore, learners gradually avoid the standard language and replace it with the unstandard language. The use of unstandard root further has an impact on the affixation and affixed word as the result of affixation. Because of the use of unstandard root bilang in affixation, the affixed word membilang as the result of affixation is also unstandard. To form the correct affixed word, kata is used as the root. Furthermore, meng-/-kan is affxed step by step. First, suffix $-k a n$ is affixed in the root kata to form the complex base katakan. Then, to form a transitive verb mengatakan, prefix meng- is affixed in the complex base katakan. However, when prefix meng- is affixed in the base which is started by consonant $/ \mathrm{k} /$, consonant $/ \mathrm{k} /$ is assimilated by nasal of the prefix.

Error identification $\quad$ : ...kami menonton televisi atau baca banyak buku-buku sampai kami capek.

The learner made an error in word choice by using adjective capek. This error occurs because the learner often interacts with Indonesian native speakers who use informal language. Therefore, the learner gradually uses informal language even in writing. In Indonesian dictionary capek is an adjective used in informal conversation. In writing, the use of adjective capek is incorrect and must be replaced by adjective capai which is the standard adjective in Indonesian.

2. Non-linguistic factors

Non-linguistic factors also have implication in learners' errors. Those factors consist of imperfect language learning and learner's community environment.

1) Imperfect language learning

The language learning design involves teaching matter and teaching method (Setyawati, 2010: 10-11). Teaching matter is related to the source, selection, arrangement, and emphasis of teaching matters. Meanwhile, teaching method is related to the technique and steps of teaching, teaching equipments, and the intensity and continuity of teaching. When the language learning is not designed perfectly, it has an impact on the accomplishment of teaching purposes. Learners are not able to master the rules of target language and they will make a lot of errors.

Having analyzed the whole data, the result indicates that linguistic errors which are made by foreign learners in their Indonesian writings are also affected by imperfect language learning. Based on the interview, foreigners learn Indonesian in different places before. The process of language learning there is focused on speaking skill for daily interaction. Meanwhile, foreigners do not only communicate oraly during living in Indonesia. They also communicate in writing, such as writing research articles or agreement of cooperation.

At Cinta Bahasa foreign learners start to learn the standard rules of Indonesian.

KULTURISTIK: Jurnal Bahasa dan Budaya E-ISSN: 2580-4456 P-ISSN: 2580-9334

Copyright $(C) 2018$ 
Vol. 2, No. 1, Januari 2018, 101

Available Online at https://ejournal.warmadewa.ac.id/index.php/kulturistik DOI: dx.doi.org/10.22225/kulturistik.2.1.679

Moreover, writing skill is practiced. However, the learning matter at Cinta Bahasa still has many shortcomings because it is arranged by one person in a relatively short time. Therefore, it has to be improved.

Besides, language learning period affects the progress of learners' language competence. When the learner learns the target language in longer time, the language competence of the learner is much better. Moreover, the amount of vocabularies that are known by the learner is greater. On the other hand, when the learner learns the target language in short time, the language competence of the learner is worse. The learner does not command the rules of target language well and knows only a small amount of vocabularies.

It is shown in their Indonesian writings. The use of capital letter and punctuation, the use of affixes, the structures of phrase and sentence, and the word choice in the writings of foreign learners who have learned Indonesian in a long time are preferable. On the other hand, in the writings of foreign learners who learned Indonesian in a relatively short time there are such code-mixing and the rules of their mother tongue are often applied in phrase and sentence structures of the target language.

2) The community environment

In this case, by the community environment is meant Indonesian native speakers who communicate with the learner in daily interaction, such as family, colleague, or friends. The community environment has implication in the progress of learners' language competence. When learners get support from their community environment, learners' language competence will improve in a relatively short time. The supports can be in the form of moral support or a chance to communicate in Indonesian. On the other hand, when learners do not get support from their community environment, the progress of learners' language competence will be slow.

It is shown in learners' writings. The command of Indonesian in the writings of foreign learners who get support from their community environment is better than the writings of foreign learners who do not get enough support from their community environment. It is also told by foreign learners in the interview. Because of the support from their community environment, foreign learners are motivated to learn Indonesian. Besides, they are easier to understand the standard rules and remember new words.

\section{CONCLUCION}

Based on the findings of this study, it can reveal that foreign learners made a great number of linguistic errors in their Indonesian writings. Those errors can be classified into four major categories, they are spelling errors, morphological errors, syntactic errors, and lexical errors. Each category is further divided into several sub-categories. The subcategories of spelling errors are errors in capitalization, error in writing affixed and root words, error in writing numbers, error in using punctuations, and error in writing borrowed word. Regarding morphology, learners made error in using the root, error in morphophonemic process, and error in using affixes. Syntactic errors in learners' writings are in terms of errors in phrase structure and errors in sentence structure. Lexical errors are divided into three sub-categories, they are the use of pleonastic words, errors in word choice, and the use of unnecessary interrogative words.

Meanwhile, the causing factors of those errors can be classified into two major factors, they are linguistic factors and non-linguistic factors. Linguistic factors involve interlingual factor, intralingual factor, and the daily use of Indonesian. Meanwhile, nonlinguistic factors involve imperfect language learning and learner's community environment.

\section{REFERENCES}

Balai Pengembangan dan Pembinaan Pustaka. (2016). Kamus besar bahasa Indonesia dalam jaringan. https://kbbi.kemendikbud.go.id.

Bloomfield, Leonard. (1995). Language. London: Henderson and Spalding.

Brown, H. Douglas. (2007). Principles of Language Learning and Teaching. New York: 


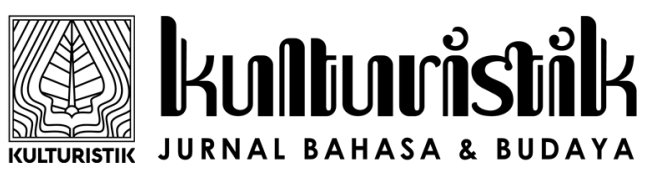

Vol. 2, No. 1, Januari 2018, 102

Available Online at https://ejournal.warmadewa.ac.id/index.php/kulturistik

DOI: dx.doi.org/10.22225/kulturistik.2.1.679

Pearson Education Inc.

Chomsky, Noam. (1971). Syntactic Structures. Paris: Mouton Publishers, The Hauge.

Corder, S. P. (1973). Introducing applied linguistics. Harmondsworth, Middlesex, England: Penguin Books.

Dulay, H., Marina Burt, \& Krashen, S. (1982). Language Two. Oxford: Oxford University Press.

Nugraha, S. T. (2008). Kesalahan-kesalahan berbahasa Indonesia pembelajar bahasa Indonesia sebagai bahasa asing: sebuah penelitian pendahuluan. Jurnal KIPBIPA IV.

Pratiwi, D. R., Rahmawati., L. E., \& Huda, M. (2016). Kesalahan berbahasa pada tulisan mahasiswa Thailand selama mengikuti pembelajaran pramenulis. In the 3rd University Research Colloquium 2016 Konsorsium LPPM PTM/PTA. Kudus.

Richards, J. C., \& Schmidt, R. (2002). Longman: dictionary of language teaching and applied linguistics (third edition). London: Pearson Education Limited.

Setyawati, N. (2010). Analisis kesalahan berbahasa Indonesia: teori dan praktik. Surakarta: Yuma Pustaka.

Siagian, E. N. (2017). Analisis kesalahan berbahasa (tulis) mahasiswa BIPA tingkat lanjut Universitas Yale, USA. In Prosiding Seminar Nasional Bahasa dan Sastra Indonesia dalam Konteks Global 2017. Jember.

Suyitno, I. (2007). Pengembangan bahan ajar untuk penutur asing (BIPA) berdasarkan analisis kebutuhan belajar. Wacana, Jurnal Ilmu Pengetahuan Budaya, Volume $9 \mathrm{~N}$.

Tarigan, H. G., \& Djago Tarigan. (2011). Pengajaran analisis kesalahan berbahasa. Bandung: Percetakan Angkasa.

Widawati, R. (2007). Kesalahan afiksasi dalam pembelajaran bahasa Indonesia bagi penutur asing. Jurnal Pendidikan Bahasa Dan Sastra. 